\title{
The Roots of North America's First Comprehensive Public Health Insurance System
}

\author{
Aleck Ostry
}

\section{Introduction}

askatchewan, sandwiched between Alberta and Manitoba, is one of three prai- rie provinces in Canada. The province consists mainly of dry prairie in the south (where it borders the states of Montana and North Dakota) and subArctic forest, giving away to tundra along its border with the North West Territories. It was opened for European settlement after the building of the Canadian Pacific Railway at the end of the nineteenth-century and grew slowly, stabilizing at a population of between 900,000 and one million after the 1940s. Until the 1950s, this sparsely settled province was sustained by a one-crop wheat economy. Saskatchewan's population distribution reflected this, as most people lived in rural areas. There were only two medium-sized cities (Regina and Saskatoon) and six smaller ones 'which anchored a network of villages and towns that covered an expanse of agricultural land larger than France'.'

Although less than eight per cent of Canadians lived in Saskatchewan in the 1940s, this province has played a large role in the development of national social policy. ${ }^{2}$ Western Canada, particularly Saskatchewan and Manitoba, was the crucible of the nation's Social Democratic movement which was based largely on the strong tradition of co-operative prairie wheat farming and marketing. Canada's first Social Democratic party, the Cooperative Commonwealth Federation (CCF), the forerunner of the New Democratic Party, was born during the Great Depression in Manitoba and Saskatchewan. The party came to power in the Saskatchewan pro-

1 Gerald Friesen, The Canadian Prairies: A History (Toronto, 1987), 282.

2 Ibid. 
vincial elections of 1944, becoming the first Social Democratic party elected in North America.

The party remained in power until 1964. During this 20-year period the CCF crafted North America's first comprehensive public health insurance scheme. Province-wide public hospital insurance was started early in the CCF's mandate in 1946 and, after an acrimonious doctors' strike in 1962, followed by public insurance for physician remuneration (Medicare) in 1962. The federal government, under the leadership of the Liberal Party, followed Saskatchewan's lead, and adopted a public scheme for hospital insurance in 1957 and Medicare in 1968. Saskatchewan, from 1944 to 1964, pioneered the development of Canada's national public health insurance plan.

Many historians of public health insurance in Saskatchewan have focussed on the development of insurance for physician's services and in particular on the conflict between government and the medical profession, culminating in the 1962 doctors' strike. ${ }^{3}$ This bitter conflict erupted when the Saskatchewan government attempted to introduce a salary plan for physicians as part of its Medicare plan. As a compromise, the salary plan was moderated to a fee-for-service payment system within the public sector, which induced Saskatchewan doctors to abandon their strike and accept Medicare.

While the government's victory over the doctors in 1962 was key to provincial, and later federal, acceptance of Medicare, it is also important to note that from 1946 to 1962 public hospital insurance operated in the province. At the same time the government and medical profession jostled for position in the growing battle over public versus private health insurance for physicians' services. The focus of this paper is an exploration of the roots of the public hospital insurance system in Saskatchewan and a description of the emerging conflict between government and doctors that played itself out in the period from 1946 to 1962.

In particular this paper attempts to answer the following questions. Why and how did North America's first public health insurance scheme develop in Saskatchewan? What were the unique features of Saskatchewan's economy, geography, and history that may have helped the development of public health insurance in this province? How did post-war economic and social development in general, and the operation of a public hospital insurance scheme in conjunction with private Medicare plans in particular, impact the subsequent development of Medicare in the province? In order to begin to answer these questions, a review of the history of public health insurance in Canada will be undertaken in the next section.

3 The following two references are the best historical descriptions of the 1962 Saskatchewan doctor's strike. E. Tollefson, Bitter Medicine: The Saskatchewan Medicare Feud (Saskatoon, 1963) and Robin Badgley and Samuel Wolfe, Doctors' Strike: Medical Care and Conflict in Saskatchewan (Toronto, 1967). 


\section{The Evolution of Public Health Insurance in Canada until World War II}

According to the Canadian Constitution, health care is the responsibility of provincial governments. It is for this reason that a provincial legislature (British Columbia's) passed Canada's first public health insurance bill. The legislation, passed by British Columbia's Liberal government in 1936, was followed by a detailed plan for its implementation. However, it was never put into action both because government coffers had been drained by the Great Depression and because of the sustained objection and public campaigning by the province's medical profession and manufacturers' association. ${ }^{4}$

In British Columbia, as the Great Depression loosened its grip, doctors were able to collect their bills more easily and so moved away from supporting public health insurance. However, in Saskatchewan, where the impact of the Great Depression was particularly severe due to its heavy dependence on wheat, the medical profession was less prosperous. As early as 1933 the Saskatchewan Medical Association had endorsed a system of public health insurance. Poverty, particularly among the province's rural doctors, acted to make them receptive to public health insurance. This poverty, and the widespread tradition of local government involvement in the delivery and payment for health services, made the notion of a province-wide public health insurance system quite appealing for both the public and the province's doctors.

On April 1, 1944, legislation for public health insurance was passed by Saskatchewan's Liberal government. The timing for this legislation was partly due to the upcoming provincial election. During the war the CCF had increased its popular appeal. One of its main campaign planks for the 1944 election was 'state medicine'. The Liberal government had passed its health insurance bill just prior to the election so that during the campaign health insurance was an uncontroversial issue championed by both the CCF and the Liberals. As historian John Archer explains:

Skatchewan Liberals were also encouraged in championing a public health insurance bill because during the war the federal Liberal government developed plans to institute a nation-wide public health insurance scheme.

Although health care was a provincial responsibility, the federal government emerged from the Second World War with more power than ever before because the provinces had given up much of their taxation authority to central government

4 M. Andrews, 'The course of medical opinion on state health insurance in British Columbia, 1919-1939', Histoire Sociale-Social History. 14 (1983), 129-41. 
in order to finance the war effort. During the war the federal government (with the support of the Canadian Medical Association) endorsed public health insurance as part of a general package of social legislation proposed for the immediate post-war reconstruction period. By 1945 the federal government had drafted a model bill for hospital insurance legislation for each of the provinces. Thus, by war's end the commitment of the federal government and organized medicine to public hospital and medical services was strong.

The attempted post-war move by the federal government into arenas of provincial constitutional authority was supported by some provinces, but not by others. The so-called 'have' provinces (that is, those provinces with a more viable personal and corporate tax base, such as Ontario and British Columbia) fought to regain tax fields they had temporarily given to the federal government during the war, while the 'have-not' provinces (for example, Saskatchewan) were happy for the Dominion to retain jurisdiction over income and corporate tax in return for federal grants. Thus, the social legislation proposed by the federal government was a powerful incentive for 'have-not' provinces to support the federal government's drive to entrench its tax base and strengthen central government. ${ }^{5}$

A federal/provincial conference was held in 1945 in order to formalise this wartime tax situation. The 'carrot' offered by the federal government was a package of social legislation, including public health insurance. The federal government tried to persuade the provinces to accept matching grants for health care services and, in return, to leave personal and corporate income tax fields under exclusive federal control. Because of opposition, mainly from Ontario, agreement was never reached. Instead federal funding for health services was postponed until 1948 when a less ambitious series of health grants was established that split the cost of building hospitals and developing health care infrastructure evenly with the provinces. ${ }^{6}$ This scheme was extremely popular with the provinces, that used these 'fifty-cent dollars' to greatly expand their health care infrastructure.

Thus, the 1944 Saskatchewan provincial election was fought with the optimistic assumption that federal funding for public health insurance would be available in the very near future. However, the collapse of the federal/provincial conference in 1945 forced a focus instead on the piecemeal introduction of public health insurance. With no federal money available in 1945, the CCF focused on the development of regional health districts and the rapid implementation of public hospital insurance. For a decade the CCF ran its hospital insurance program with no hope of federal aid. When the federal government passed national hospital insurance legislation in 1957, the CCF finally had the resources to consider introducing Medi-

5 Malcolm Taylor, Health Insurance and Canadian Public Policy, 2nd ed, (Montreal, 1987).

6 Ibid. 
care. $^{7}$ The ability of the CCF to introduce both medical and hospital insurance was severely compromised following the 1945 failure at provincial and federal co-operation. As we shall see in the next section, this failure widened the window of opportunity for Saskatchewan doctors, improving their strategic position in relation to the CCF government.

\section{Rural Medicine in Saskatchewan before 1944}

\section{Organization of Rural Hospitals}

Rural Saskatchewan possessed an unusually strong co-operative movement which initially developed in order to market wheat. In 1945, the average farmer belonged to four or five co-operatives. Saskatchewan co-operative associations had a combined membership of at least 300,000, and it is likely that 'most of Saskatchewan families, especially in the rural areas belonged to some form of co-op'. Co-operative institutions permeated rural life and underpinned local rural governments, giving them enormous strength and resiliency.

The Union Hospital Districts (UHD) were almost a natural organizational form within rural communities operating in a collective capacity. The provincial legislature facilitated the early development of 'hospital co-ops' in 1916 when it provided municipalities with the authority to band together to form Union Hospital Districts. A Union Hospital District was essentially a co-operative consisting of several rural municipalities which banded together in order to expand the tax base for the construction and operation of rural hospitals. By 1920 there were ten of these in the province and by 1944 there were twenty-three. ${ }^{10}$

The legislature gave the UHD's authority to tax local property owners to finance the construction and operation of hospitals. Until 1934, property owners were the tax base. However, in 1934 the Rural Municipality Act was amended so rural municipalities could assess non-property owners a flat hospital tax. Through the Municipal Medical and Hospital Services Act of 1939, municipalities raised taxes

7 Jack Granatstein, Canada 1957-1967: The Years of Uncertainty and Innovation, (Toronto, 1986), 172.

8 Seymour Lipsett, Agrarian Socialism: The Cooperative Commonwealth Federation in Saskatchewan, A Study in Political Economy (Toronto, 1950).

9 T. McLeod, Tommy Douglas: The Road to Jerusalem (Edmonton, 1987), 176.

10 Malcolm Taylor, 'The Saskatchewan Hospital Services Plan: A Study in Compulsory Health Insurance', Ph.D. diss., University of California Berkley, 1949), 83. 
from both property and individuals. Thus, by the end of World War II, many rural municipalities had developed fairly sophisticated local infrastructures and expertise for the purpose of tax collection and the management and operation of hospitals.

Even with the passing of the Municipal Medical and Hospital Services Act, which gave rural municipalities an expanded tax base to fund their public health services, rural municipalities were still hard pressed to fund these appropriately. However, rural municipalities had a strong political voice in the province, as they had their own co-op, the Saskatchewan Association of Rural Municipalities (SARM). SARM was a strong political voice which pushed consistently, throughout the Great Depression years, for provincial and federal government funding for hospitals and medical care in order to relieve financial pressure on rural municipalities.

\section{Physician Remuneration and Physician Manpower in Rural Districts}

Residents of rural Saskatchewan also developed a cooperative solution to pay doctors. This became known as the Municipal Doctor System (MDS). The first MDS was established in 1914 when the municipality of Sarnia, which was about to lose its physician, offered him a $\$ 1,500$ annual salary to stay. Sarnia offered the contract without provincial legislative approval. In 1916, the legislature gave municipal councils authority to levy a tax to pay for doctor services, and by 1931 fifty-two municipalities had contracts for service with physicians. ${ }^{11}$ Thus, by the 1940 s, local government in many rural regions of the province had made hospital care and doctors' services available at relatively low cost to most residents within their jurisdiction.

Another element in the evolution of health reform was, of course, the attitude of Saskatchewan's doctors, particularly towards the cooperative elements of the system in rural regions. The Great Depression hit Saskatchewan doctors very hard, forcing about 20 per cent of the province's doctors to leave. ${ }^{12}$ Those who remained faced financial hardships that helped create a positive feeling for state intervention in medicine. The level of financial hardship was so severe for Saskatchewan doctors that 'in December 1932 the government placed many doctors on "relief" by guaranteeing minimum monthly payments of $\$ 50$ or $\$ 75$ to those doctors working in the most severely affected drought areas'. ${ }^{13}$

Thus, during the Great Depression rural doctors saw 'government interference' in medical practice in an extremely positive light. This sentiment increased

11 Taylor, 1987, 72.

12 Badgley and Wolfe, 1967, 12.

13 Ibid., 12. 
throughout the Great Depression as Saskatchewan doctors became more dependent on provincial government supplements to rural municipalities and to the MDS to ensure steady incomes. It is not surprising that under the particularly severe conditions of the Great Depression in rural Saskatchewan in 1933, the provincial Medical Association enthusiastically endorsed a comprehensive publicly funded health insurance plan. ${ }^{14}$

The difficult economic situation facing Saskatchewan doctors during the Great Depression is reflected in a steep decline in physician manpower. During the Great Depression Saskatchewan had the lowest doctor to population ratio in Canada. ${ }^{15}$ In 1921 the ratio of doctors to the Saskatchewan population was $1 / 1445$. This ratio had declined to $1 / 1579$ by 1931 . The war probably accelerated the exodus of doctors, as in 1943 the total number of doctors in the province reached its lowest point at $408 .{ }^{16}$ A shortage of nurses also occurred in the province, which in 1942 had one registered nurse per 696 persons, compared to a Canadian average of one per 461 persons. ${ }^{17}$

The Great Depression and the war emptied Saskatchewan of its doctors so that, when the CCF came to power in 1944, it faced acute-care and personnel shortages, particularly in the rural health care sector. Those doctors, especially from rural areas, who had remained in the province were used for state involvement in the provision of health care service. They had suffered more than most Canadian doctors during the Great Depression, and many had been placed on government relief. At the same time, the general population in the province had suffered more severely than that of any other province. ${ }^{18}$ While these conditions were particularly difficult in the countryside, what was happening in Saskatchewan's cities?

\section{Urban Medicine in Saskatchewan before 1944}

The Union Hospital Districts and Municipal Doctor Systems were features of rural Saskatchewan. They provided basic hospital and medical services within a region and were universal, so that everyone, including the most disenfranchised members of the community, was covered. In the cities, which were less impoverished than the countryside, direct fee-for-service medicine was the rule until private medical plans were introduced in the late 1930s.

14 Ibid., 12.

15 Ibid., 12.

16 Taylor, 1987, 78.

17 Taylor, 1987, 79.

18 Badgley and Wolfe, 1967, 4. 
These plans, made possible by the Mutual Medical and Hospital Benefit Association Act of 1938 and endorsed by the Canadian Medical Association (CMA), were voluntary and often physician-owned and managed. The plans covered physicians' services provided either at home or at the office. The physician billed the plan rather than the patient for his fee that in all plans was paid on a fee-for-service basis. Plans did not charge utilisation fees, and there was very little 'extra-billing' by physicians.

There were advantages and disadvantages to the voluntary plans newly available in the cities compared to the municipal doctor schemes of the rural regions. Voluntary plans gave the consumer some choice of doctors, unlike the MDS, which effectively limited patient choice to the municipally employed doctor or doctors. Also, MDS's did not usually pay for specialist services or surgery, whereas these were covered in many of the voluntary plans. Thus, the voluntary plans offered consumers more choice. However, unlike the MDS, voluntary plans excluded 'high risk' patients, so that the worst health insurance risks (the poor and the sick) were excluded from coverage.

Private plans were slow to establish themselves. In 1939 in Regina a group of laymen started a medical insurance plan and began to hire Regina doctors and pay them on a salary rather than fee-for-service basis. In response, Regina doctors set up their own medical insurance plan and exerted such pressure that local doctors refused to work in the laymen's salaried plan. Two years later the Saskatoon Mutual Medical and Hospital Benefit Association was organised. By 1945, there were four insurance plans in the province covering approximately 50,000 people. ${ }^{19}$ Medical Services Incorporated (MSI) and Group Medical Services (GMS) were organised and controlled by the medical profession and became the largest plans in the province. They paid doctors on a fee-for-service basis and by the mid-1940s had enrolled approximately six per cent of the population.

19 Badgley and Wolfe, 1967, 24. 


\section{The Geography of Health Care Reform in Saskatchewan after 1944}

\section{The Health Planning Commission}

When the CCF was formed in 1933, it declared in its founding document that 'every civilised community owed its citizens a properly organised public health care system' ${ }^{20}$ This commitment was reinforced by party leader Tommy Douglas's harrowing personal medical experiences. As a boy he developed a bone disease in his leg and because of his family's poverty, he languished in hospital for three years until one of the best bone surgeons in the region took an interest in his case and attended him properly (and without payment). Douglas felt strongly that poverty should not deprive others of good medical care. Accordingly, immediately on coming to power he took on the post of Minister of Health which he kept until 1949. Most of the innovations in health care financing and planning were put in place during his tenure.

One of the first things Douglas did upon taking office in 1944 was to establish the Health Planning Commission (HPC) in order to plan initially for the introduction of state-funded hospital insurance and the subsequent development of comprehensive public health insurance. This was an amazingly complex task because the civil service was hostile to CCF ideology and because no one had ever attempted to introduce public health insurance on this scale in North America.

The HPC was set up outside the existing civil service framework in part because the CCF had inherited a civil service structure and personnel built up under decades of Liberal government rule which was 'notorious for its appointment on the basis of loyalty and obligation to the Liberal Party'. ${ }^{21}$ Outside experts were also brought in because no one in North America had attempted to implement a comprehensive public health insurance scheme and the expertise was simply not available in the province.

As Mombourquette has pointed out, the HPC moved quickly and radically, so that by 1947 many of the major CCF health reforms had been set in motion. ${ }^{22}$ Within two years the HPC had surveyed all of the province's hospitals, devised a hospital insurance scheme, and set up the infrastructure to collect hospital taxes (using the municipal tax gathering system already in place over most rural regions

20 McLeod, 1987, 145.

21 Taylor, 1985, 87.

22 D. Mombourquette, 'An Inalienable Right: The CCF and Rapid Health Care Reform, 1944-1948', Saskatchewan History, 43:3 (1991), 101-116. 
in the province) to sign up beneficiaries, and to pay the hospitals. The province also set up a system of capital grants (four years in advance of the 1948 federal grants) to encourage the building and upgrading of hospitals. At the same time, for administrative purposes the CCF established fourteen health regions in Saskatchewan. ${ }^{23}$

\section{The Saskatchewan Hospital Insurance Plan}

When the CCF took power they expected to obtain federal cash to establish a system of insured medical and hospital care simultaneously and within a few years. However, because of federal foot dragging in general and in particular the collapse of the $1945 \mathrm{federal} /$ provincial constitutional conference, this did not happen, and, instead, the CCF could not afford to implement comprehensive public health insurance and settled to 'go it alone' with hospital insurance. Hospital insurance came into the province and operated without a system of state insured doctors' services at a time in the province's history when economic, demographic, and institutional power began to shift from countryside to the cities.

The operation of a system of hospital insurance on its own and the establishment of hospital construction grants resulted in an infusion of capital into the hospital infrastructure that was particularly beneficial to the hospitals in the city. Increasingly, as road networks were improved, city hospitals with their superior technologies were seen as centres in which rural patients could be serviced with more ease. The demographic shift and the provision of public hospital insurance increased the resources of urban hospitals and the catchment area for patients, therefore increasing the size of the urban medical market, which tended to strengthen fee-for-service medicine and private health insurance plans.

\section{Reforms in Rural Regions}

In 1946 in Health Region No. 1, located around the town of Swift Current (found in the south-east of the province near the American border and representing about five per cent of the province's population), the provincial government started North America's first comprehensive health insurance scheme funded by a combination of a local health tax and provincial sales tax. ${ }^{24}$ As Feather has pointed

23 William Lougheed, Underwriting Canadian Health: An Economic View of Welfare Programs (Toronto, 1957).

24 Ostry, A. (1995) 'Prelude to Medicine: Institutional Change and Continuity in Saskatchewan, 1944-1962', Praire Forum, 20, 1, 87-106. This article outlines the political background, particularly the interplay between the federal and provincial government which limited 
out, this was a demonstration project upon which the CCF hoped to build by expanding it to the remaining thirteen health regions. ${ }^{25}$

According to Tollefson, the major reason why this region was chosen to demonstrate comprehensive public health insurance was because it had suffered particularly badly during the Great Depression and the accounts of most of the general practitioners in the region were 'far in arrears' ${ }^{26}$ This meant that the GP's in the region were very receptive to the plan. The municipalities within the region were also interested in the new plan as the region would receive a health grant from the province, resulting in an injection of much needed provincial money.

After the election the CCF also encouraged the expansion of the MDS's and the UHD's using health grants to encourage training of personnel and upgrading of equipment. In the five years between 1944 and 1949, fifty-five additional UHD's were established so that by 1949 there were a total of seventy-eight covering one third of the province and providing about 40 per cent of Saskatchewan's hospital beds. Similarly, the MDS's were expanded and, by 1948, 107 municipalities, fiftynine villages, and fourteen towns had contracts with a total of 180 doctors. ${ }^{27}$

The expansion of Union Hospital Districts, the establishment of health regions, and the successful start of the 'Swift Current' scheme were indications that the provincial government wanted to move quickly in spite of the federal government's fading resolve on state medicine. Rural Saskatchewan experienced an injection of expertise and capital as the government aggressively built on and expanded the cooperative health infrastructure and traditions already in place.

The major province-wide reform initiated by the CCF during this time was the establishment of the Saskatchewan Hospital Insurance Plan (SHIP). It is very important to note that, although the establishment of the HPC, the setting up of the Swift Current demonstration project, the creation of health regions, and the expansion of UHD's and MDS's all generated opposition among Saskatchewan's doctors, SHIP was greeted with relative silence by a profession which recognised that this portion of the CCF's reform would operate in its best interests.

the ability of the CCF to introduce health reform as originally planned.

25 Joan Feather, 'Impact of the Swift Current Health Region: Experiment or Model?' Prairie Forum, 16: 2 (1991), 225-248; Joan Feather, 'From Concept to Reality: Formation of the Swift Current Health Region', Prairie Forum, 16:1 (1991), 59-80.

26 Tollefson, 1963, 40.

27 Ibid., 41. 


\section{Physician Remuneration in Rural Regions}

Resistance to reform proceeded down several parallel tracks. One of these was the avoidance of situations where doctors were salaried by governments or agencies of government. As long as Saskatchewan was depressed and doctors were poor, direct salary arrangements with the municipality were an economically viable option for rural practitioners. However, with the fading of the Great Depression, doctors began to pressure councils for payment on a fee-for-service rather than a salary basis. Thus, under the Liberal administration of 1941 provincial legislation was amended to allow payment of doctors within the MDS on a fee-for-service as well as a salary basis. ${ }^{28}$

This move away from direct salary arrangements with municipalities even penetrated the provincial government's pilot project in Swift Current. By 1949 the approximately forty doctors in the Swift Current Health Region had negotiated a fee-for-service payment scheme with the Regional Health Board. However, the board kept the doctors' fees at 75 per cent of the recommended fee schedule set by the Saskatchewan College of Physicians and Surgeons with a global cap on expenditures that effectively controlled the rate of increase in Swift Current doctors' incomes. The profession in the rest of the province witnessed this income squeeze with alarm and increasingly agitated against the spread of the Swift Current model to other rural health regions. ${ }^{29}$

\section{Physician Remuneration in Urban Regions}

The growth of private insurance plans was another track down which resistance to reform grew, particularly in the cities. This resistance grew as the plans expanded rapidly in the first half of the 1950s. Although the growth of these plans slowed somewhat toward the end of the 1950s, the annual rate of membership growth averaged twenty per cent per year throughout the decade. ${ }^{30}$ (See Table 1.)

By the early 1950s urban physicians increasingly viewed expansion of either the Swift Current model or the MDS as a threat, because in a political sense their success encouraged the government along the road to state medicine, and also because this expansion represented a loss of market share for the private plans. Both the political and market threats were intertwined and formed the basis for the medical profession's increasingly strident opposition to 'state medicine'.

28 Taylor, 1949, 87.

29 Saskatchewan Government, Public Health Annual Report (Saskatoon, 1956), 93.

30 Ibid., 98. 
Table 1. Growth in Membership for MSI and

GMS Voluntary Insurance Plans from 1951

to 1960.

\begin{tabular}{crrrr}
\hline Year & MSI & GMS & Total & $\begin{array}{r}\% \\
\text { Annual } \\
\text { Growth }\end{array}$ \\
\hline 1951 & 48352 & 17186 & 65538 & \\
1952 & 74382 & 22281 & 96663 & 48 \\
1953 & 92530 & 25157 & 117687 & 22 \\
1954 & 107874 & 30906 & 138780 & 18 \\
1955 & 122191 & 37070 & 159270 & 15 \\
1956 & 150649 & 45000 & 195649 & 23 \\
1957 & 175000 & 61730 & 236730 & 21 \\
1958 & 192351 & 62822 & 255173 & 8 \\
1959 & 211514 & 68201 & 279715 & 10 \\
1960 & 214002 & 74816 & 288818 & 3 \\
\hline Source: Saskatchewan, Public Health Annual Report \\
(1961), p. 93.
\end{tabular}

The key to understanding physician promotion of their private plans lies not just in the economic advantage that accrued to physician-owners and operators of the plans. Another reason was the increased autonomy that the plans provided. The managers of the plans (usually physicians) set the schedule of fees and offered consumers a range of plan options. That is, the private plans offered doctors an ability to negotiate the price of their services with themselves. This was very different from a situation where doctors were salaried by government agencies. With the latter arrangement, physicians became civil servants with less economic clout and a greater opportunity for government to interfere directly in the practice of medicine.

\section{Expansion of Private Plans into the Rural Health Care Market}

Although the growth of private plans occurred mainly in the cities, they made some inroads in rural areas as the insurance companies made a deliberate attempt to slow both the spread of the MDS and the Swift Current pilot project. They were quite successful in rural areas because, by 1955, the private plans had negotiated contracts with sixty out of approximately 180 rural municipalities, towns, and villages. ${ }^{31}$ Thus, the early expansion in UHD's and MDS's following the CCF ascension to power began to slow and reverse itself after 1948. (See Figure 1.)

31 Saskatchewan Government, Public Health Annual Report (Saskatoon, 1955). 
Figure 1. Change in the number of rural municipal doctor plans between 1945

and 1961.

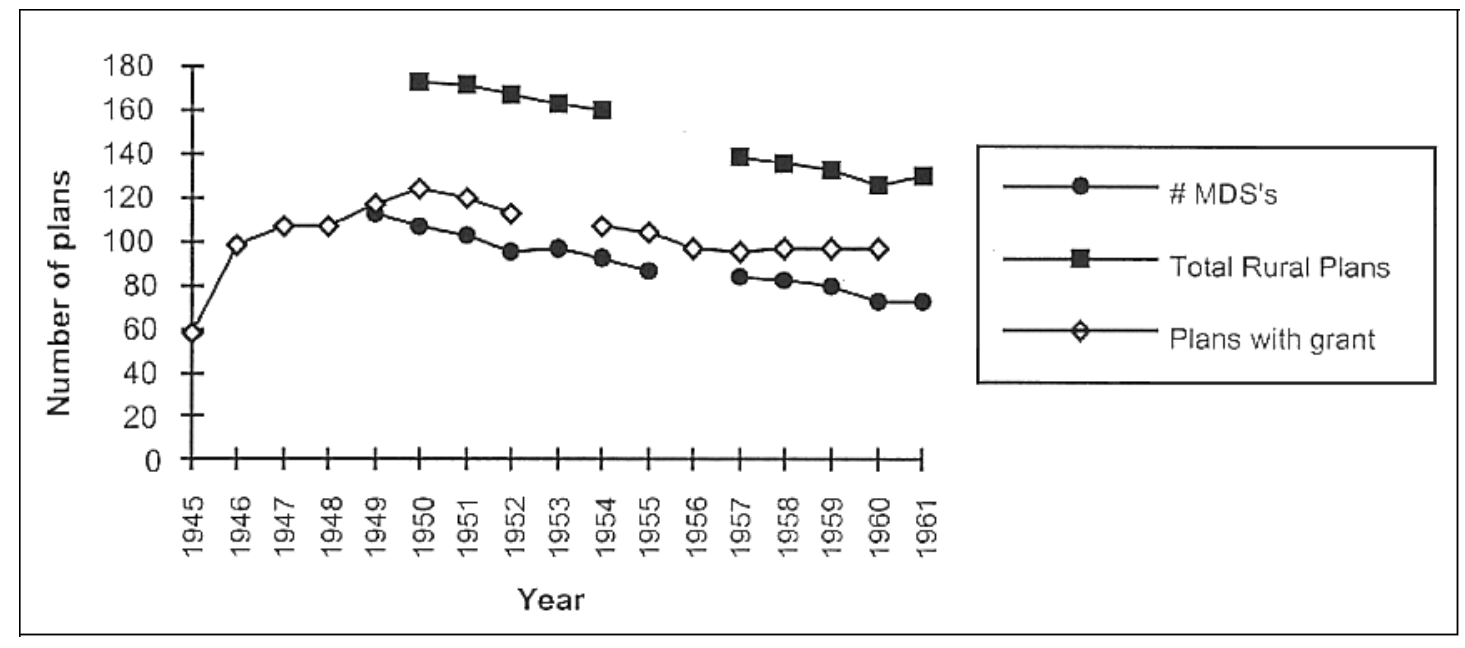

The government was very aware of the threat posed by the spread of physiciancontrolled private health insurance plans in rural regions and viewed their expansion with alarm, as it feared they would cream off the paying section of the market leaving the state to pick up the tab for the destitute and the working poor. Also, if middle class patients were captured by these plans, the government would run into electoral resistance in its attempts to tax this class to pay for medical insurance for everyone in the province. This concern is apparent in the Saskatchewan Public Health Annual Report of 1956 which states:

There is virtually no governmental supervision over the benefits, coverage, or costs of the voluntary medical care plans. Theoretically, municipalities require approval by the Minister of Public Health before entering into agreements for provision of medical care to local residents. In practice, however, such agreements are undertaken between municipal councils and the voluntary plans without ministerial approval. This presents a problem which remains to be solved. The real difficulty is that the voluntary plans leave unprotected some 25 per cent of persons in the municipality and their costs are very much higher than those plans providing prepaid medical care under official auspices. ${ }^{32}$

Some rural municipalities abandoned their MDS in favour of private plans partly because 'of the improvement of highways throughout the province and the corresponding desire of the people for the services of specialists who are located in the larger cities ${ }^{33}$ Clearly such improvements had increased the expectations of rural residents. The private plans gave the municipality a way of meeting these higher expectations, as they could buy a range of specialist services not available under the

32 Annual Public Health Report, 1956, 97.

33 Ibid., 25. 
less flexible MDS. Of course, because the plans usually had exclusions and conditions, a municipality purchasing such a plan usually reduced the scope of coverage in the community.

In an attempt to slow the spread of private plans in rural Saskatchewan the government tried to interest other rural health regions in their Swift Current model. A relevant passage in the Saskatchewan Public Health Report of 1956 is worth quoting at some length.
Because of the success of the regional medical care plan in the Swift Current area, several other health regions expressed interest during the year in launch- ing new regional medical care plans. This reached the point of proposals in the Regina Rural Health Region and the Assiniboia Health Region, contemplating the establishment of prepaid plans covering the whole population of these regions. At the request of the regional boards, statistical data were compiled for calculation of the benefits and costs of medical care plans, fashioned after the Swift Current experience but modified to suit the wishes of the regional repre- sentatives. After favourable action by the regional boards, the regional health councils of both of these regions met in the summer of 1955 and voted over- whelmingly to favour such plans, but to submit the question to public refer- enda. During the late summer and fall months serious difficulties developed on the international wheat market and farmers became acutely short of cash. Meanwhile, the organized medical profession expressed considerable opposi- tion to these regional proposals, favouring instead enrollment of the people into voluntary plans. ${ }^{34}$

The government was stopped in its efforts to expand the Swift Current model to the other thirteen health regions. There is no question that the medical profession organised effectively to stop the expansion of the Swift Current model in these two regions. But, it is also likely that local farmers (hit as they were by a downturn in the price of wheat) were not anxious to face the increased taxes needed to finance the regional plan. Also,

as movement from the farms to the cities grew there was an increasing need for a portable type of health plan that would protect a man wherever he went rather than just within the confines of his municipality. This need began to be filled in the 1940s by voluntary health insurance companies. ${ }^{35}$

The portability and flexibility of the voluntary plans compared to the MDS made the latter increasingly unattractive.

34 Annual Public Health Report, 1956, 112.

35 Badgley and Wolfe, 1967, 9. 
The CCF continued to make half-hearted efforts to stop municipalities from opting out of the MDS by refusing to give a municipality its health grant (used to pay for its doctor) if council contracted with a private plan. Because the health grants were small, many rural councils ignored the government and went ahead without their approval to negotiate with the private plans. By 1955 the MDS system was in decline. The Swift Current demonstration project was effectively contained, although it continued to operate in the region until 1962 when it was integrated into the new provincial Medicare plan. Private plans were expanding rapidly and the momentum for change shifted away from the government.

\section{Expansion of the Hospital Infrastructure and Physician Supply}

After 1947 the injection of public money via the Saskatchewan Hospital Insurance Plan and government hospital construction grants led to an immediate and rapid expansion of the hospital infrastructure and utilisation across the province. 'Where Saskatchewan had the lowest number of hospital beds per capita of any province in 1944 , it had the highest in $19544^{36}$ This turn-around in infrastructure enhanced the ability of doctors to practice their craft. More hospitals, more beds, and more equipment meant greater publicly funded access to the tools of the doctor's trade. This expansion in infrastructure and financing of hospital care helped bring doctors back into the province. The expansion of hospital capacity and public hospital insurance, the 1950s return of doctors to the province, and the increased vigour of the private plans were inextricably linked together, producing by the end of the 1950s a larger and economically more secure medical profession and a more rapid expansion of urban compared to rural medical markets.

Saskatchewan doctors had, by the mid-1950s, access to good hospital facilities and relatively high incomes. With these conditions, there was a substantial migration of doctors into the province. Although the population of Saskatchewan increased by only 11 per cent between 1949 and the eve of the doctors' strike in 1962 , the number of doctors practising in the province increased by 43 per cent, from 614 to 881. (See Table 2 and Figure 2.) Although a medical school was in operation in the province by the mid-1950s, the bulk of new doctors practising in the province in the mid-1950s consisted of post-war immigrants, mainly from Britain. 
Table 2. Number of Registered Physicians in Saskatchewan by Year (1949-62).

\begin{tabular}{cccc}
\hline Year & $\begin{array}{c}\text { Number } \\
\text { of Physicians }\end{array}$ & Year & $\begin{array}{c}\text { Number } \\
\text { of Physicians }\end{array}$ \\
\hline 1949 & 614 & 1956 & 835 \\
1950 & 633 & 1957 & 864 \\
1951 & 662 & 1858 & 886 \\
1952 & 713 & 1959 & 925 \\
1953 & 750 & 1960 & 895 \\
1954 & 776 & 1961 & 900 \\
1955 & 811 & 1962 & 881 \\
\hline
\end{tabular}

Source: Saskatchewan College of Physicians and Surgeons Brief to the Saskatchewan Government's Advisory Planning Committee on Medical Care (1962), p. 39.

Figure 2. Number of Registered Physicians and their Ratio to the Total Population of Saskatchewan (1949-77).

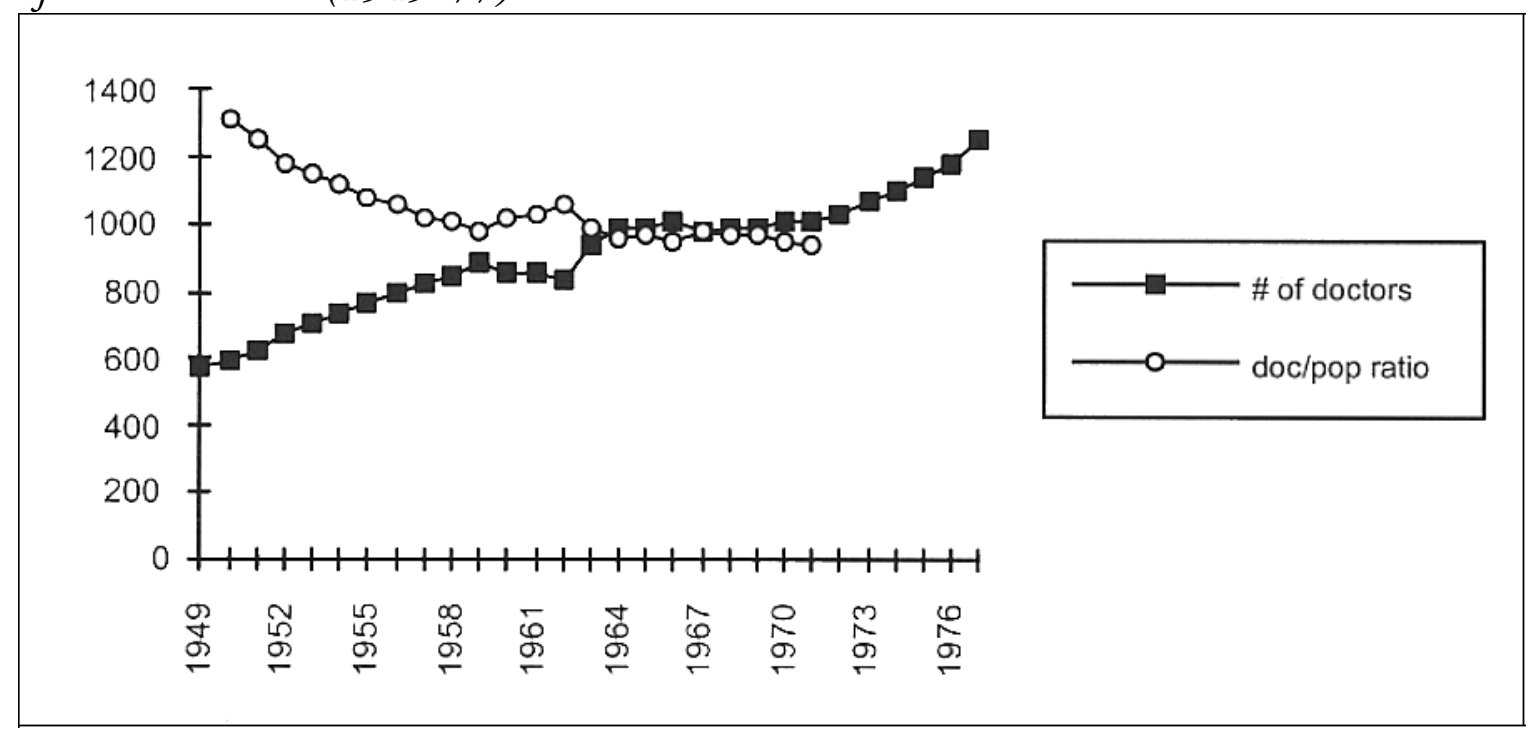

By 1961, 54 per cent of doctors in Saskatchewan practised in the two major cities of Saskatoon and Regina, although these cities contained only 22 per cent of the provincial population. Also, by the early 1960s, 50 per cent of doctors in the province had been in practice for less than a decade. ${ }^{37}$ This was due to the influx of immigrant doctors to Saskatchewan in the 1950s and the ageing, retirement, and deaths of Saskatchewan's 'country' doctors. The doctors who had weathered the Great Depression, who had staffed the Municipal Doctor Systems in rural Saskatchewan, and who had viewed government involvement in the provision of rural health services favourably were, by the late 1950s, older men nearing the end of their careers.

37 Badgley and Wolfe, 1967, 28. 
In contrast many of the immigrant doctors were from Britain; they had fled the 1945 nationalisation of their health services and had relocated in Saskatchewan cities. ${ }^{38}$ Ideologically, this meant that many of the new doctors were opposed to CCF plans for Medicare. In other words, on the eve of the doctors strike in 1962, the demography of the medical profession had shifted from rural to urban location and from 'home-grown' to immigrant in composition.

The capitalisation and expansion of the hospital infrastructure in terms of plant and personnel were unparalleled in Saskatchewan compared to any other province between 1944 and 1962, as both hospital construction grants and SHIP funnelled public money into the hospital system. In 1947 the number of rated beds per 1,000 people in the province was 5.1. This figure peaked at 6.7 in 1951, an increase of 31 per cent. The total availability of beds shot up in this five year period and the intensity with which patients who were in these beds were serviced also increased dramatically, from 1,678 to 2,209 days of patient care per one thousand beneficiaries (an increase of $31 \%$ ). This increase in utilisation of hospital services may have been due to the unmet need within the population which had, relative to other parts of Canada, experienced such huge deprivation due to the Great Depression and the war.

These numbers illustrate that, relative to other parts of Canada, the hospital infrastructure and the rate at which it was utilised expanded dramatically following the introduction of hospital construction grants and SHIP, and that these high utilisation rates continued throughout the 1950s. This means that doctors were admitting patients into the province's hospitals in numbers and at rates far greater than pre-SHIP averages and much higher than national averages. This injection of public funds enhanced the doctors' ability to deliver services and their potential for increasing the range of services provided. It also enhanced the attractiveness of their private health insurance plans. It is no wonder that, by 1958, Saskatchewan doctors were the best paid in the country. ${ }^{39}$

\section{Conclusion}

North America's first comprehensive health insurance system was built on the back of a rural tradition of co-operative economic and institutional development which evolved in the first half of the twentieth-century in the province of Saskatchewan. These institutions and traditions were unique in Canada and go some way towards explaining why public health insurance system evolved in this province.

38 Tollefson, 1963.

39 Granatstein, 1986, 171. 
The strength of these rural traditions and institutions was rapidly eroded by the demographic shift from country to city in the fifteen years following the end of World War Two, as well as by the increasing post-war prosperity derived mainly from the non-agricultural economy. Yet, it was the election of a Social Democratic government (as well as the fact it managed to remain in power for a sustained period of 16 years) committed to public health care insurance that provided the political will and continuity to ensure survival of these older rural traditions in the new public health insurance scheme.

Post-war economic development in Saskatchewan brought unprecedented prosperity to the provinces. Increasing prosperity against the background of a comprehensive hospital insurance plan and the expansion of medical facilities such as hospitals increased doctors incomes and their scope of practice. As the private Medicare plans grew, the medical insurance industry and the medical profession were opposed mainly by the political commitment of the CCF and public opinion. However, by the mid-1950s 'the government was becoming less skilled in managing health policy moves, Health Ministers changed, bureaucrats came and went. Meanwhile the Saskatchewan Medical Association was gearing up for battle. ${ }^{40}$

The expansion of private medical plans as well as federal government foot dragging over the financing of public hospital insurance and Medicare both limited the CCF's ability to introduce health reform according to its original timetable. Although the CCF moved quickly to implement hospital insurance, they did not aggressively expand the scope of existing municipal doctor plans. The government seemingly was unable to commit all its efforts to supporting and expanding UHD's and MDS's and yet, at the same time, it half-heartedly moved to stop the profession from expanding its own insurance companies.

These ambivalent tactics on the part of CCF health planners and the defeat of their regionalisation policy by 1955 - due in part to the successful expansion of urban-based voluntary insurance plans for physician services - led to an abandonment of the ideologically based HPC health planning model and the substitution of a model acceptable to the Saskatchewan Medical Association. As Shillington points out, a key factor in the movement towards a 'medical model' in health planning was the profession's successful provision of an alternative to the state funding of medical care in the form of the private health insurance plans. ${ }^{41}$

The decisive battle between third party payers was fought in the mid-1950s in rural regions. The government's inability to expand the Swift Current model to the other thirteen health regions and build on the MDS tradition in the face of aggressive expansion of urban-based private insurance plans into rural Saskatchewan

40 Anne Crichton, 'Evolution of Health Services in Canada' (Unpublished book manuscript cited with permission of the author, 1993), 301.

41 H. Shillington, The Road to Medicare in Canada (Toronto, 1972), 181. 
health markets was a measure of the profession's new power relative to government. This new strength was based in the cities of Saskatchewan, as by the early 1960s the rural tradition of co-operative medicine had been virtually swept away.

Alec Ostry, Ph.D., Department of Health and Epidemology, University of British Columbia 